\title{
SOSIALISASI BUDIDAYA IKAN LELE MUTIARA PADJADJARAN DI KELOMPOK PETERNAK LELE CILEUNYI
}

\author{
Ibnu Dwi Buwono, Iskandar dan Roffi Grandiosa \\ Departemen Akuakultur, Fakultas Perikanan Dan Ilmu Kelautan, Universitas Padjadjaran \\ E-mail: ibnu.dwi.buwono@unpad.ac.id,0812ibnu@gmail.com
}

\begin{abstract}
ABSTRAK. Pengabdian kepada masyarakat ini bertujuan untuk mendiseminasikan keunggulan lele mutiara Padjadjaran untuk memperbaiki pertumbuhan benih dan peningkatan produksi ikan lele yang terdapat pada kelompok peternak ikan lele Cileunyi (KPLC) di kecamatan Cileunyi Kelurahan Cimekar Kabupaten Bandung. Upaya ini dilakukan untuk menjamin ketersediaan benih terjamin terutama pada musim kemarau. Metode penyuluhan menggunakan pelatihan teori dan praktek lapang agar terjadi interaksi intensif antara peserta dengan fasilitator untuk kegiatan fisik di lokasi. Kegiatan pengabdian difokuskan kepada evaluasi pertumbuhan benih ikan lele mutiara Padjadjaran (lele transgenik G4) dan ikan lele mutiara non-transgenik sebagai kontrol yang dipelihara pada kolam hapa KPLC (out door) dan akuarium di hatchery (in door). Hasil pelatihan ini berhasil menarik minat pembudidaya lele KPLC untuk mengganti teknologi konvensional beralih ke teknologi baru yang diperkenalkan. Indikator keberhasilan ini ditunjukkan oleh meningkatnya pengetahuan, keinginan bekerja sama dan minat untuk membudidayakan ikan lele mutiara Padjadjaran. Pembesaran benih ikan lele mutiara Padjadjaran oleh pembudidaya menghasilkan pertumbuhan $87-100 \%$ lebih tinggi dibandingkan ikan lele biasa (non-transgenik). Produk ikan lele unggulan ini layak dan menguntungkan untuk dijadikan model percontohan pengembangan budidaya ikan lele pada masyarakat untuk menambah pendapatan sebagai usaha sampingan.
\end{abstract}

Kata kunci: G4; gen hormon pertumbuhan; lele mutiara Padjadjaran; pembudidaya; transgenesis

ABSTRACT. This community service aims to disseminate the advantages of Padjadjaran mutiara catfish to improve fingerling growth and increase catfish production in the Cileunyi catfish farmer group (KPLC) in Cileunyi sub-district, Cimekar village, Bandung regency. This effort is made to ensure the availability of guaranteed fingerlings, especially in the summer season. The extension method uses theoretical training and field practice so that there is intensive interaction between participants and facilitators for physical activities at the location. The service activities were focused on evaluating the growth of Padjadjaran mutiara catfish (G4 transgenic catfish) and non-transgenic mutiara catfish as controls that were kept in the KPLC Hapa pond (out door) and aquarium in the hatchery (in door). The results of this training succeeded in attracting the interest of KPLC catfish farmers to replace conventional technology and switch to the new technology introduced. This indicator of success is indicated by increased knowledge, willingness to cooperate and interest in cultivating Padjadjaran mutiara catfish. Grow out of Padjadjaran mutiara catfish fry by farmers resulted in 87-100\% higher growth than non-transgenic mutiara catfish. This superior catfish product is feasible and profitable to be used as a pilot model for developing catfish cultivation in the community to increase income as a side business.

Keywords: G4; growth hormone gene; Padjadjaran mutiara catfish; farmers; transgenesis

\section{PENDAHULUAN}

Wilayah Cileunyi merupakan kecamatan di kabupaten Bandung sebagai perbatasan antara kabupaten Sumedang dan Bandung yang dilalui oleh sungai Cikeruh dan menjadi sumber air untuk kolam budidaya ikan lele dan kolam pemancingan di desa Cileunyi Wetan dan Cileunyi Kulon. Budidaya ikan lele tradisional merupakan komoditas budidaya air tawar dominan yang diusahakan masyarakat pada kedua desa tersebut. Peningkatan permintaan komoditas ikan lele sebagai bahan pangan kebutuhan masyarakat Jawa Barat, menyebabkan peningkatan permintaan benih lele terus meningkat dari tahun ke tahun sebagai dampak dari peningkatan jumlah populasi penduduk perkotaan. Kondisi ini mengakibatkan unit-unit pembenihan rakyat (UPR) yang dikelola secara perorangan maupun kelompok di wilayah kabupaten Bandung tidak dapat memenuhi permintaan benih secara berkesinambungan oleh karena terbatasnya stok induk-induk lele matang gonad di tingkat pembenih lele. Ditinjau dari segi kontinuitas produksi benih lele yang dihasilkan kelompok pembenih di sentra budidaya lele Cileunyi kabupaten Bandung masih terdapat hambatan khususnya penyediaan jumlah stok induk lele untuk kebutuhan pemijahan induk setiap bulan. Hal ini menuntut adanya pengadaan stok induk ikan lele matang gonad untuk kegiatan pemijahan setiap bulan, dalam upaya memenuhi kebutuhan permintaan benih ikan lele secara kontinyu.

Perbaikan pertumbuhan ikan lele melalui program pemuliaan menggunakan selective breeding hanya meningkatkan peningkatan sebesar $40 \%$ dari semula, sementara penggunaan teknologi transgenesis (penyisipan gen hormon pertumbuhan ikan lele dumbo, Clarias gariepinus Growth Hormone, $\mathrm{CgGH})$ pada ikan lele mutiara dikenal sebagai lele mutiara Padjadjaran (Gambar 1) mampu meningkatkan pertumbuhan ikan sebesar $150-200 \%$ pada G2 dan sebesar 100-150\% pada G3 (Iswanto et a.1, 2014; Buwono et al., 2019a; Buwono et al., 
2021). Stabilitas pewarisan karakter pertumbuhan G0 sampai G3 pada ikan lele mutiara Padjadjaran (G4) ini menunjukkan bahwa $\mathrm{GH}$ eksogen $(\mathrm{CgGH})$ diwariskan secara permanen pada setiap generasi. Karakter pertumbuhan super ikan lele mutiara Padjadjaran ini memiliki potensi untuk menggantikan jenis ikan lele yang dibudidayakan kelompok KPLC.

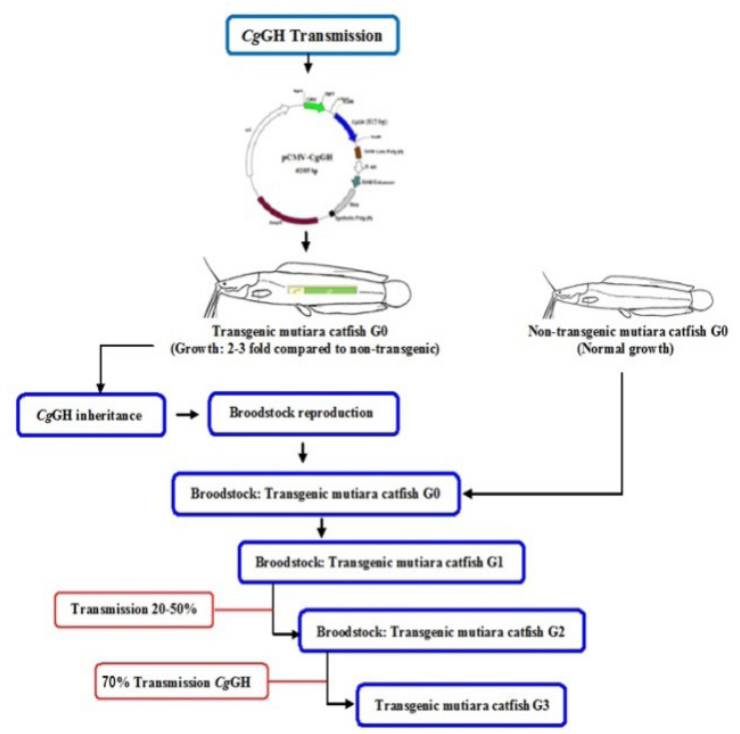

Gambar 1. Pembentukan ikan lele mutiara Padjadjaran (mutiara transgenik- $\mathrm{Cg} \mathrm{GH}$ ) (Buwono et al., 2021)

Lokasi pembenihan ikan lele yang dijadikan untuk kegiatan pengabdian masyarakat terintegrasi riset terletak di wilayah Kecamatan Cileunyi (daerah Cikalang Kaler Kecamatan Cileunyi Kulon). Komunitas pembenih ikan lele tersebut diketuai oleh Bp. Wahyu Jusuf Fiandani membina sekitar $10-$ 12 anggota pembesaran benih lele dalam kelompok peternak ikan lele "KPLC" yang dikukuhkan tanggal 13 Februari 2018. Pemilihan ini didasarkan atas sistem budidaya yang diterapkan masih bersifat konvensional, jenis ikan lele yang digunakan menggunakan strain mutiara non-transgenik dan pemijahan alami. Ditinjau dari teknik pembenihan yang dilakukan oleh kelompok peternak lele KPLC menganut sistem pemijahan alami, waktu pemijahan induk tidak dapat dipacu agar cepat matang gonad dan menggantungkan pada tingkat kematangan induk lele secara alami. Lamanya waktu pematangan gonad induk secara alami ini sedikit banyak berpengaruh terhadap kontinuitas produksi benih yang dihasilkan tidak dapat menghasilkan benih secara rutin setiap bulan sehingga terdapat kolam-kolam pembesaran benih yang puso akibat tidak ada kegiatan pembesaran larva menjadi benih (tahap pendederan). Untuk mengatasi permasalahan tersebut, program penyuluhan teknologi produksi benih ikan lele mutiara Padjadjaran dilakukan yang dimulai dari teknik pematangan gonad calon induk, seleksi induk untuk pemijahan semi buatan sampai dengan penanganan telur dan pemeliharaan larva lele secara terkontrol. Program penyuluhan ini diharapkan dapat memperbaiki kondisi teknik pembenihan yang ada dan dianut guna mengatasi kendala yang dialami kelompok.

\section{METODE}

Metode pelaksanaan pengabdian tersebut menggunakan model penyuluhan, yang mencakup kegiatan belajar dan mengajar sambil mempraktekkan di lapangan (proses kerja) atau learning by doing. Hasil kegiatan penyuluhan memberikan dampak terhadap perubahan akan pengetahuan (knowledge), cara berfikir (thinking)dan ketrampilan(skill)sertaperasaan dansikap untuk mengadopsi suatu teknologi yang diperkenalkan. Proses pembelajaran merupakan proses belajar seumur hidup yang tidak terbatas pada pendidikan formal saja, dan terjadi proses pertukaran pengetahuan (sharing knowledge) dalam mengembangkan kemampuan untuk ber-tindak (Kasryno, 1983). Peningkatan ketrampilan dilakukan dengan pemberian pelatihan baik secara lisan (penyuluhan menggunakan hand out atau modul teknis pengerjaan suatu proses teknologi) maupun dengan praktek dalam demplot percontohan agar transfer teknologi dapat disederhanakan bentuk penyampaiaannya sehingga mudah dipahami dan diterima oleh akal dalam pikiran masyarakat. Pelatihan dimaksudkan untuk memperbaiki kemampuan kerja seseorang dalam kaitannya dengan rutinitas kerja sehari-hari dalam upaya mencapai tujuan (Scott, 1996).

Kegiatan pengabdian melibatkan kelompok pembenih lele (Komunitas Peternak Lele Cileunyi, KPLC) dilakukan pada dua lokasi, yaitu indoor hatchery Fakultas Perikanan Dan Ilmu Kelautan, Jatinangor dan outdoor di kolam hapa KPLC, Cikalang Kaler Kecamatan Cileunyi Kulon. Fokus kegiatan pengabdian berbasis riset pada evaluasi pertumbuhan benih ikan lele mutiara Padjadjaan (transgenik G4) dan ikan lele mutiara non-transgenik sebagai kontrol (pembanding) hingga ukuran konsumsi yang dipelihara pada kolamhapa KPLCdan akuarium di hatchery FPIK Unpad dengan kepadatan ikan yang berbeda sebagai uji pertumbuhan (Gambar 2a dan 2b). Rancangan acak lengkap (RAL) dengan tiga kali ulangan yang diaplikasikan pada dua lokasi mennggunakan perlakuan padat penebaran yang berbeda. Kepadatan ikan yang diterapkan pada uji pertumbuhan benih ikan G4 di kolam hapa mengacu pada padat tebar yang biasa dilakukan masyarakat pembenih lele, yaitu padat tebar tinggi (perlakuan A 150 ekor/ 700 L), sedang (perlakuan B 120 ekor/ 700 L) dan rendah (perlakuan C 100 ekor/700 L). Benih ikan G4 (transgenik dan non-transgenik) yang digunakan dalam uji pertumbuhan memiliki rata-rata berat awal 2,5-4,0 g per ekor pada umur 3 minggu 
setelah menetas. Mengingat tempat dan wadah pemeliharaan ikan di indoor hatchery terbatas, maka dilakukan penyesuaian terhadap rancangan perlakuan secara porposional yaitu menggunakan volume air untuk masing-masing akuarium sebesar 70 L. Penyesuaian juga dilakukan terhadap padat penebaran yang proporsional dengan perlakuan yang diterapkan pada outdoor hatchery, yaitu perlakuan A : 15 ekor / $70 \mathrm{~L}$ air, B : 12 ekor / $70 \mathrm{~L}$ air dan C : 10 ekor / $70 \mathrm{~L}$ air, sementara perlakuan kontrol D: 15 ekor / $70 \mathrm{~L}$ air. Jenis pakan yang digunakan mengikuti tahapan perkembangan tumbuh ikan lele, yaitu pakan PF (Prima Feed) 500 selama 10 hari, selanjutnya diberikan PF 800 untuk 7 hari dan diberikan PF 1000 untuk 12 hari. Pakan berikutnya sesuai dengan pertumbuhan ikan diberikan pakan komersial hiprovite 781-1 untuk 10 hari, kemudian pakan hiprovite 781-2 untuk 7 hari dan selanjutnya diberikan pakan 781 polos hingga pemeliharaan tiga bulan sebagai evaluasi pertumbuhan ikan G4 . Taraf pemberian pakan sebanyak 5\% bobot biomass dengan dua kali pemberian setiap hari dan pergantian air dilakukan 3 kali setiap minggu.

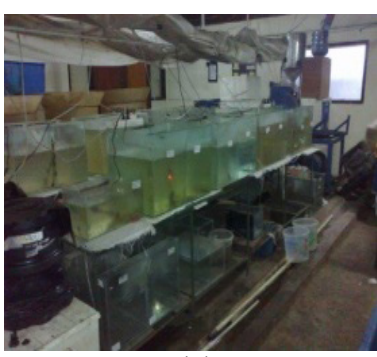

(a)

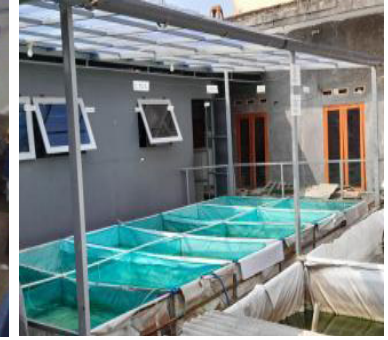

(b) sumber: dokumentasi penulis

Gambar 2. Lokasi uji pertumbuhan ikan G4. (a) Indoor hatchery (b) Outdoor hatchery

Pelaksanaan kegiatan ini dimulai tanggal 23 Mei-7 Agustus 2021, dengan pengambilan data pertumbuhan dan jumlah pakan secara langsung setiap minggu untuk monitoring pertumbuhan ikan G4 hingga pemeliharaan 60 hari. Kedua data primer selanjutnya dianalisis secara statistik menggunakan SigmaPlot 12.3 untuk evaluasi pertumbuhan ikan lele mutiara Padjadjaran G4.

\section{HASIL DAN PEMBAHASAN}

\section{Transfer teknologi pembenihan ikan lele}

Penyuluhan dan pelatihan yang diberikan oleh tim PPM FPIK Unpad secara berkala setiap dua minggu, membuahkan hasil dengan peningkatan pemahaman kelompok pembenih lele, khususnya adopsi teknologi maturasi induk untuk kegiatan produksi benih lele berkelanjutan. Secara teoritis, aplikasi teknologi reproduksi yang disampaikan kepada kelompok pembenih sebagai khalayak sasaran dengan penayangan video dan presentasi visual teknik pemijahan induk lele dapat diserap dan diekspresikan dengan seringnya peserta pelatihan bertanya tentang materi yang didiskusikan tersebut. Inti pelatihan difokuskan pada materi teknik maturasi, penggunaan strain induk unggul, pemilihan induk jantan dan betina sebagai breeder yang selektif dan potensial dipijahkan, serta teknik pemijahan semi buatan, menarik para peserta untuk menyimak tahap demi tahap kegiatan breeding tersebut untuk perbaikan dalam teknik pemijahan konvensional yang selama ini dianut para pembenih. Intensitas diskusi selama penyuluhan berkala tersebut, memberikan keyakinan para pembenih lele di kelompok KPLC untuk mencoba mengganti praktik pembenihan dengan teknologi baru yang diperkenalkan tim FPIK Unpad dengan harapan dapat meningkatkan produksi larva dan benih lele.

Secara alami, pemijahan induk ikan lele mengikuti musim pemijahan, yang dapat terjadi pada awal dan akhir musim penghujan. Kondisi pemijahan musiman ini sangat berhubungan dengan ketersediaan air yang berlimpah pada saat musim penghujan. Oleh karenanya, pemijahan alami ikan lele hanya memungkinkan dilakukan pada saat musim hujan (Rustidja, 2014, Yalçin et al., 2001). Umumnya induk ikan lele betina, menjelang musim penghujan, kematangan gonadnya mendekati masak (mature), demikian pula halnya dengan induk ikan jantan yang matang gonad (Cek \& Yilmaz, 2007). Berdasarkan kenyataan ini, maka pemijahan ikan lele hanya dapat dilakukan satu kali dalam setahun, yaitu hanya pada musim hujan. Namun demikian, penerapan teknik maturasi gonad induk lele yang diberikan selama penyuluhan dan dilakukan pada musim kemarau, dapat memberikan hasil kematangan gonad induk lele. Indikasi ini menunjukkan bahwa induk ikan lele dapat dipijahkan baik pada musim penghujan dan musim kemarau. Teknik maturasi gonad tersebut memberikan manfaat dalam penyediaan induk ikan matang gonad baik musim kemarau dan penghujan, sehingga dapat mendukung kontinuitas produksi benih pada dua musim dalam setahun.

Berdasarkan hasil penyuluhan dan diskusi dengan para komunitas peternak lele Cileunyi (KPLC) di ruang diskusi hatchery gedung 4 FPIK Unpad Jatinangor, disepakati bahwa untuk praktek pemijahan induk lele mutiara transgenik G3 menggunakan metode pemijahan semi buatan (stimulasi dengan injeksi hormon untuk memacu pemijahan induk secara mandiri) (Gambar 3).

Penggunan teknik reproduksi pemijahan induk lele ini dimaksudkan untuk mengenalkan teknik baru dalam membenihkan ikan lele yang dapat dilakukan secara mandiri tanpa tergantung dari musim pemijahan lele (umumnya diinduksi oleh musim hujan). Penggunaan hormon reproduksi ini (Ovaprim 
dan HCG) diperlukan untuk mensinkronkan ovulasi dan spermiasi dari induk yang matang gonad sehingga dapat meningkatkan jumlah telur yang terbuahi (Lang et al., 2003). Kegiatan maturasi gonad calon induk ikan ini memegang peranan penting dalam menyediakan induk-induk lele matang gonad yang siap untuk dipijahkan setiap waktu sesuai kebutuhan yang diinginkan. Teknik maturasi gonad ini merupakan salah satu solusi pemecahan masalah untuk menyediakan induk lele siap dipijahkan kapanpun untuk memenuhi kontinuitas kebutuhan benih yang diminta setiap bulan. Guna melatih pembenih KPLC agar terbiasa dan terlatih dalam melakukan pemijahan semi buatan pada induk lele mutiara transgenik G3, maka pelatihan teori secara intensif tentang induksi kematangan gonad induk, seleksi induk siap pijah dan memeriksa induk matang gonad dan siap dipijahkan diperlukan untuk meningkatkan pemahaman pembenih. Sebelum dilakukan praktek pembenihan secara langsung di kolam milik pembenih KPLC, terlebih dahulu dilakukan demo pemijahan semi buatan pada induk lele mutiara transgenik G3 di bak pemijahan indoor hatchery FPIK Unpad Jatinangor, untuk membuktikan perlunya induksi hormonal agar setiap pemijahan induk lele berhasil. Keberhasilan ini perlu dibuktikan secara langsung kepada para pembenih KPLC agar nantinya tidak ragu untuk menggunakan teknik pemijahan ini sebagai perbaikan metode pemijahan konvensional yang selama ini dianut oleh pembenih (Gambar 4).

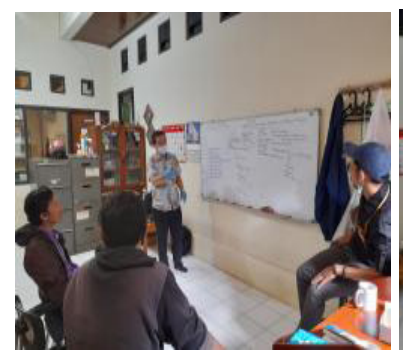

(a)

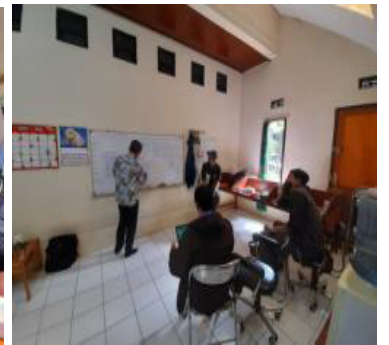

(b)

sumber: dokumentasi penulis

Gambar 3. Penyuluhan praktek pemijahan. (a). teori reproduksi (b). Induksi pemijahan

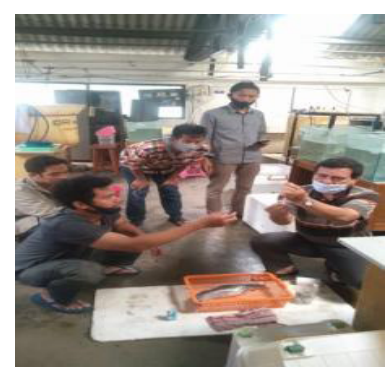

(a)

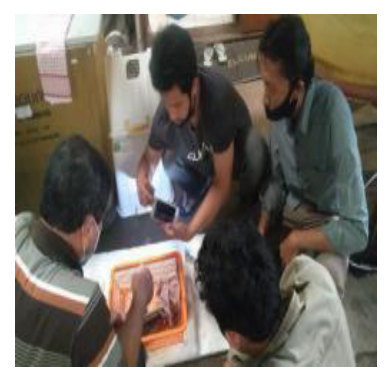

(b) sumber: dokumentasi penulis

Gambar 4. Injeksi hormon induk G3 untuk produksi G4 (a) injeksi ikan betina (b) injeksi ikan jantan
Diskusi secara intens dilakukan oleh para instruktur (tim peneliti PPM Unpad) dengan KPLC dalam upaya mensukseskan pemijahan lele yang berhasil dengan tepat sasaran dan mengantisipasi berbagai kendala yang dapat mempengaruhi ketidakberhasilan pemijahan.

\section{Animo pembudidaya lele KPLC untuk meng- adopsi teknologi baru}

Hasil evaluasi karakter tumbuh benih ikan G4 selama pemeliharaan 60 hari menunjukkan bahwa ikan lele mutiara transgenik G4 tumbuh lebih cepat daripada ikan lele mutiara non-transgenik G4 pada umur yang sama dan lama waktu pemeliharaan yang sama baik di indoor maupun outdoor (Gambar 5a dan 5b). Selama 60 hari pemeliharaan ikan G4 pada indoor hatchery, menunjukkan bahwa pertumbuhan ikan lele mutiara transgenik G4 2 kali lebih tinggi dibandingkan ikan lele mutiara non-transgenik (peningkatan 100\%), sedangkan pada outdoor hatchery peningkatan pertumbuhan ikan lele mutiara transgenik G4 sebesar 87\% (1,74 kali) dibandingkan ikan non-transgenik. Hasil penghitungan rata-rata bobot ikan G4 (60 hari pemeliharaan) dengan perlakuan perbedaan padat menunjukkan ikan lele transgenik tetap tumbuh cepat tidak dipengaruhi tingginya padat penebaran, namun ikan non-transgenik pertumbuhannya melambat pada padat tebar tinggi. Kondisi pertumbuhan lambat pada ikan non-transgenik yang diperlakukan dengan padat tebar tinggi ini juga ditunjukkan oleh hasil penelitian pada ikan sturgeon Amur (Acipenser schrenckii Brandt) memiliki performa pertumbuhan lambat ketika dipelihara dengan padat tebar tinggi selama 70 hari pemeliharaan (Ren et al., 2018). Kepadatan ikan yang tinggi dalam kolam menyebabkan ikan menjadi stress dan menurunkan kadar hormon tiroid yang selanjutnya menurunkan sekresi hormon pertumbuhan (growth hormone/GH) dengan kompensasi penurunan laju pertumbuhan (Refaey et al., 2018). Pada ikan channel catfish (Ictalurus punctatus) juga menunjukkan bahwa peningkatan padat penebaran ikan secara signifikan menurunkan pertumbuhan ikan (Bosworth et al., 2015).

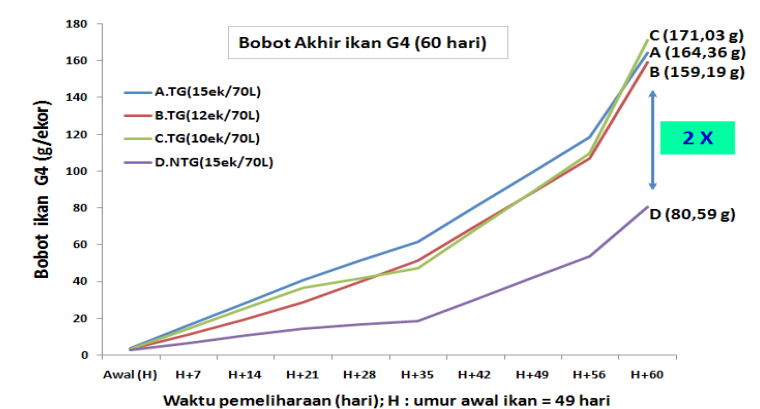

sumber: dokumentasi penulis

Gambar 5a. Pertumbuhan ikan lele mutiara Padjadjaran G4 pada indoor (TG:transgenik; NTG: nontransgenik) 


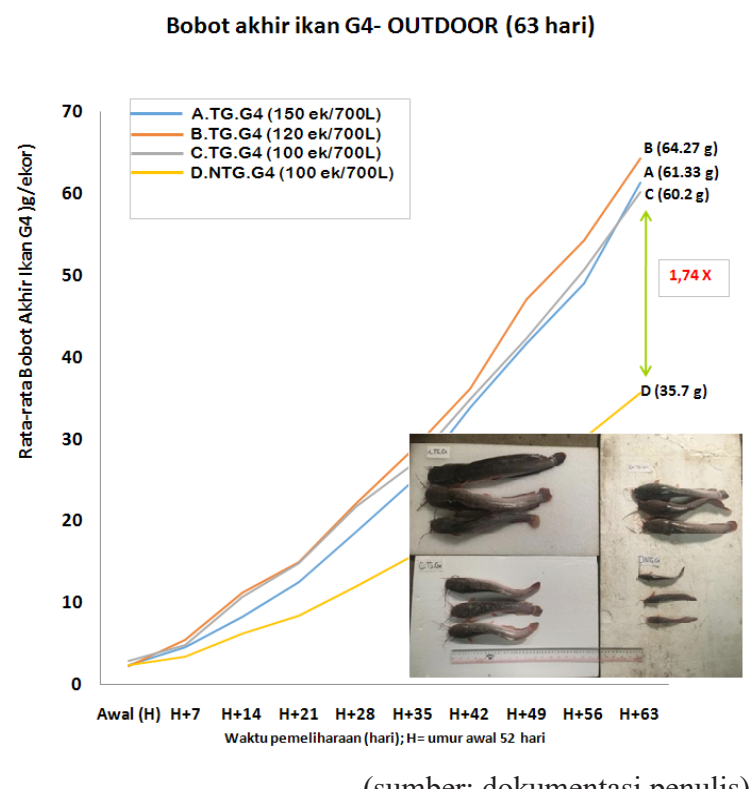

(sumber: dokumentasi penulis)

Gambar 5b. Pertumbuhan ikan lele mutiara Padjadjaran G4 pada outdoor (TG:transgenik; NTG: nontransgenik)

Penelitian bersama dan pendampingan secara komprehensif dalam operasional riset untuk mengevaluasi pertumbuhan ikan lele mutiara Padjadjaran G4 untuk menentukan keunggulan genetik yang diberikan oleh tim PPM FPIK Unpad secara berkala setiap dua minggu membuahkan hasil dengan peningkatan pemahaman kelompok pembenih lele bagaimana teknik mempercepat pertumbuhan ikan lele dan teknologi produksi benih secara massal berkelanjutan (Tabel 1).

Tabel 1. Evaluasi adopsi teknologi baru

\begin{tabular}{|c|c|c|}
\hline Tahapan & $\begin{array}{c}\text { Respon dan aksi } \\
\text { pembudidaya }\end{array}$ & $\begin{array}{c}\text { Indikator } \\
\text { capaian }\end{array}$ \\
\hline $\begin{array}{l}\text { 1.Transfer } \\
\text { ilmu dan } \\
\text { teknologi } \\
\text { reproduksi ikan }\end{array}$ & $\begin{array}{l}\text { Kelompok KPLC } \\
\text { mampu menyerap dan } \\
\text { memahami teknik } \\
\text { produksi benih ikan }\end{array}$ & $\begin{array}{l}\text { Meningkatnya } \\
\text { animo } \\
\text { pembudidaya } \\
\text { lele untuk } \\
\text { menerapkan } \\
\text { teknologi } \\
\text { baru yang } \\
\text { diperkenalkan }\end{array}$ \\
\hline $\begin{array}{l}\text { 2.Praktek } \\
\text { pemijahan } \\
\text { semi buatan } \\
\text { induk hingga } \\
\text { penanganan } \\
\text { larva ikan lele }\end{array}$ & $\begin{array}{l}\text { Tingkat ketrampilan } \\
\text { pembenih kelompok } \\
\text { KPLC sudah meningkat } \\
\text { dalam penerapan teknik } \\
\text { penyuntikan induk ikan }\end{array}$ & $\begin{array}{l}\text { Hasil uji coba } \\
\text { penyuntikan } 2 \\
\text { pasang induk lele } \\
\text { berhasil memijah } \\
100 \%\end{array}$ \\
\hline $\begin{array}{l}\text { 3.Pendampingan } \\
\text { pelaksannan uji } \\
\text { pertumbuhan } \\
\text { ikan lele } \\
\text { mutiara } \\
\text { Padjadjaran } \\
\text { di kolam hapa } \\
\text { KPLC }\end{array}$ & $\begin{array}{l}\text { Minat dan kesediaan } \\
\text { untuk memelihara ikan } \\
\text { lele mutiara Padjadjaran } \\
\text { selama } 2 \text { bulan } \\
\text { pemeliharaan tinggi } \\
\text { diikuti meningkatnya } \\
\text { partisipasi dalam } \\
\text { kegiatan ganti air, } \\
\text { pemberian pakan, } \\
\text { penimbangan bobot dan } \\
\text { pengukuran panjang } \\
\text { ikan }\end{array}$ & $\begin{array}{l}\text { Keunggulan } \\
\text { produk akhir } \\
\text { riset bersama } \\
\text { ditunjukkan oleh } \\
\text { ukuran rata-rata } \\
\text { bobot tubuh } \\
\text { ikan lele mutiara } \\
\text { Padjadjaran lebih } \\
\text { tinggi dari pada } \\
\text { ikan lele normal. }\end{array}$ \\
\hline
\end{tabular}

Kegiatan adopsi teknologi perbenihan ikan lele dalam penerapan ilmu pengetahuan dan teknologi yang dikembangkan oleh peneliti dari Fakultas Perikanan Dan Ilmu Kelautan Universitas Padjadjarankepadamasyarakat pembenihikanlele ini pada dasarnya merupakan proses memasyarakatkan hasil-hasil penelitian yang telah dilakukan oleh perguruan tinggi untuk dapat dimanfaatkan pengguna agar hasil penelitian memberikan nilai tambah secara riil dalam memperbaiki usaha yang telah berkembang di masyarakat (Nuryanti \& Swastika, 2011). Secara teoritis, aplikasi teknologi reproduksi yang disampaikan kepada kelompok pembenih sebagai khalayak sasaran dengan penayangan video dan presentasi visual uji pertumbuhan ikan lele mutiara Padjadjaran di lokasi kolam pembenih KPLC menarik para peserta untuk menyimak tahap demi tahap kegiatan breeding tersebut untuk perbaikan dalam teknik pemijahan konvensional yang selama ini dianut para pembenih. Intensitas diskusi selama penyuluhan berkala tersebut, memberikan keyakinan para pembenih lele di kelompok KPLC untuk mengganti praktik pembenihan dengan teknologi baru yang diperkenalkan tim FPIK Unpad dan benih lele mutiara Padjadjaran di kolam pembesaran lele masing-masing anggota kelompok dengan harapan dapat meningkatkan produksi panen ikan lele (Gambar 6).

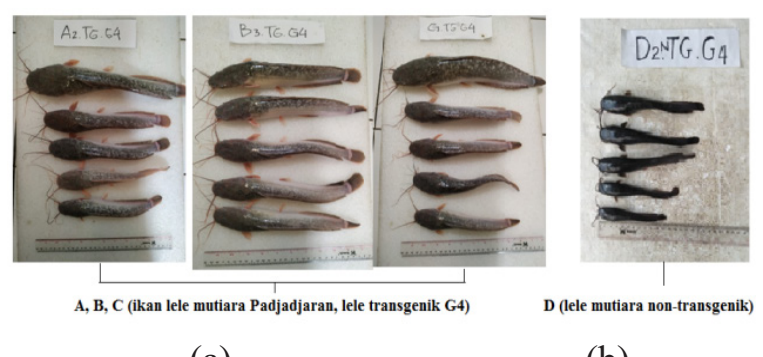

(a)

(b)

Gambar 6. Produk riset bersama. (a) mutiara Padjadjaran (b) non-transgenik

\section{SIMPULAN}

Hasil uji lapangan (baik indoor dan outdoor) selama 60 hari pemeliharaan, menunjukkan bahwa karakter tumbuh ikan lele mutiara Padjadjaran meningkat $87-100 \%$ dibandingkan dengan ikan non-transgenik layak dan menguntungkan untuk dikomersialisasikan sebagai ikan lele unggulan di masyarakat pembudidaya ikan lele. Waktu pemeliharaan pada indoor hatchery hingga mencapai ukuran konsumsi (100 g/ekor) hanya memerlukan waktu 109 hari dan pada outdoor memerlukan waktu 120 hari. Sebaliknya ikan pembanding (ikan lele non-transgenik) baru mencapai ukuran 50-80 g/ekor pada pemeliharaan 120 hari. Persepsi masyarakat pembudidaya ikan lele KPLC terhadap hilirisasi 
dan komersialisasi ikan unggulan ini sangat tinggi, mengingat bukti peningkatan produksi panen telah ditunjukkan dalam kolaborasi riset bersama ini.

\section{UCAPAN TERIMAKASIH}

Kegiatan pengabdian masyarakat yang berbasis riset RKDU tahun 2020-2021 ini telah memberikan banyak manfaat khususnya pemberian paket bantuan pakan, jaring hapa, shelter kolam uji outdoor dan saung sebagai tempat pertukaran ilmu kepada masyarakat pengguna. Ucapan terima kasih kami sampaikan kepada Direktorat Riset, Pengabdian Masyarakat (DRPM) Universitas Padjadjaran tahun anggaran 2020-2021 sebagai pemberi dana dan juga disampaikan terima kasih sebesarnya kepada Bapak Yusuf Wahyu Fiandani selaku ketua KPLC atas kesediaan penggunaan kolam sebagai tempat uji lapangan pertumbuhan lele mutiara Padjadjaran.

\section{DAFTAR PUSTAKA}

Bosworth, B, Ott, B, Torrans. L. 2015. Effects of stocking density on production traits of Channel Catfish $\times$ Blue Catfish hybrids. North American Journal of Aquaculture, 77(4), 437-443.

Buwono ID, Junianto J, Iskandar I, Alimuddin A. 2019a. Growth and expression level of growth hormone in transgenic mutiara catfish second generation. Journal of Biotech Research [ISSN: 1944-3285], 10: 102-109.

Buwono ID, Iskandar I, Grandiosa R. 2021. Growth hormone transgenesis and feed composition influence growth and protein and amino acid content in transgenic G3 mutiara catfish (Clarias gariepinus). Aquaculture International 29 (2): 1-21.

Cek S, Yilmaz E. 2007. Gonad development and sex ratio of sharptooth catfish (Clarias gariepinus Burchell, 1822) cultured under laboratory conditions. Turk J Zoology, 31: 35-46.
Iswanto B, Imron R. Suprapto, Marnis H. 2014. Perakitan strain ikan lele Clarias gariepinus (Burchell, 1822) cepat tumbuh melalui seleksi individu : pembentukan populasi dasar sintetis. Prosiding Forum Teknologi Akuakultur 2012. Hlm. 1197 - 1210.

Kasryno F. 1983. Prospek Pembangunan Ekonomi Pedesaan. Yayasan Obor Indonesia. Jakarta.

Lang RP, Romaire RP, Tiersch YR. 2003. Induction of early spawning of channel catfish in heated earthen ponds. North American Journal of Aquaculture, 65: 73-81.

Nuryanti S, dan Swastika D. 2011. Peran kelompok tani dalam penerapan teknologi pertanian. Forum Penelitian Agro Ekonomi. Vol.29 No.2. Hlm. 115-128. Pusat Penelitian Sosial Ekonomi Pertanian. Bogor.

Refaey MM, Li D, Tian X, Zhang Z, Zhang X, Li L, Tang R. 2018. High stocking density alters growth performance, blood biochemistry, intestinal histology, and muscle quality of channel catfish Ictalurus punctatus. Aquaculture, 492: 73-81.

Ren Y, Wen H, Li Y, Li J. 2018. Stocking density affects the growth performance and metabolism of Amur sturgeon by regulating expression of genes in the GH/IGF axis. Journal of Oceanology and Limnology, 36: 956-972.

Rustidja. 2014. Pemijahan buatan ikan-ikan daerah tropis. Seri penuntun praktis perikanan. Bahtera Press Malang. $196 \mathrm{hlm}$.

Scott JC. 1996. Kelembagaan akomodatif: pendekatan pembangunan perikanan yang berorientasi pada peningkatan aksesibilitas perikanan rakyat. Buletin ilmiah Perikanan. Fakultas Perikanan, Universitas Brawijaya Malang.

Yalçin S, Solak K, Akyurt I. 2001. Certain reproductive characteristics of the catfish (Clarias gariepinus Burchell, 1822) living in the river Asi, Turkey. Turk. J. Zool. 25: 453-460. 